\title{
Spermine attenuates carotid body glomus cell oxygen sensing by inhibiting L-type $\mathrm{Ca}^{2+}$ channels
}

\author{
S.H. Cayzac ${ }^{a}$, A. Rocher ${ }^{\text {b }}$, A. Obeso ${ }^{\text {b }}$, C. Gonzalez ${ }^{\text {b }}$, D. Riccardi ${ }^{\text {a }}$, P.J. Kemp ${ }^{\mathrm{a}, *}$ \\ a Division of Pathophysiology and Repair, School of Biosciences, Cardiff University, Museum Avenue, Cardiff CF10 3AX, UK \\ ${ }^{\mathrm{b}}$ Instituto de Biologia y Genetica Molecular (CSIC) and CIBER de Enfermedades Respiratorias (ISCiii), Universidad de Valladolid, 47005 Valladolid, Spain
}

\section{A R T I C L E I N F O}

\section{Article history:}

Accepted 15 September 2010

\section{Keywords:}

Carotid body

Hypoxia

L-type calcium channels

Polyamines

Calcium-sensing receptor

\begin{abstract}
A B S T R A C T
An increase in intracellular $\mathrm{Ca}^{2+}$ is crucial to $\mathrm{O}_{2}$ sensing by the carotid body. Polyamines have been reported to modulate both the extracellular $\mathrm{Ca}^{2+}$-sensing receptor $(\mathrm{CaR})$ and voltage-gated $\mathrm{Ca}^{2+}$ channels in a number of cell types. Using RT-PCR and immunohistochemistry, the predominant voltage-gated $\mathrm{Ca}^{2+}$ channels expressed in the adult rat carotid body were $\mathrm{L}\left(\mathrm{Ca}_{\mathrm{V}} 1.2\right)$ and $\mathrm{N}\left(\mathrm{Ca}_{\mathrm{v}} 2.2\right)$-type. CaR mRNA could not be amplified from carotid bodies, but the protein was expressed in the nerve endings. Spermine inhibited the hypoxia-evoked catecholamine release from isolated carotid bodies and attenuated the depolarization- and hypoxia-evoked $\mathrm{Ca}^{2+}$ influx into isolated glomus cells. In agreement with data from carotid body, recombinant $\mathrm{Ca}_{\mathrm{v}} 1.2$ was also inhibited by spermine. In contrast, the positive allosteric modulator of CaR, R-568, was without effect on hypoxia-induced catecholamine release from carotid bodies and depolarization-evoked $\mathrm{Ca}^{2+}$ influx into glomus cells. These data show that spermine exerts a negative influence on carotid body $\mathrm{O}_{2}$ sensing by inhibiting L-type $\mathrm{Ca}^{2+}$ channels.
\end{abstract}

(c) 2010 Elsevier B.V. All rights reserved.

\section{Introduction}

The naturally occurring polyamines, putrescine, spermidine and spermine, are small organic molecules which are normally present in plasma at micromolar concentrations (Chaisiri et al., 1979). Whilst necessary for optimal cell growth at these physiological concentrations (Tabor and Tabor, 1984), polyamines increase both as a consequence of normal hormonal variations (Gilad et al., 2002) and during pathologies, such as malignant transformation (Casero and Marton, 2007), brain injury (Dogan et al., 1999a,b), or neuronal ischemia (Li et al., 2007). Moreover, synaptic vesicles contain spermine at concentrations as high as $2 \mathrm{mM}$ (Masuko et al., 2003), suggesting that their co-release with classical neurotransmitters will result in very large concentrations being present in the synaptic cleft during neuronal activity. Polyamines are positively charged at physiological $\mathrm{pH}$ and this polycationic nature endows them with greater affinities than other mono- and di-valent cations for acidic components of proteins. This makes them ideal candidates for regulators of ion channels and receptors involved in cellular $\mathrm{Ca}^{2+}$ homoestasis (Li et al., 2007). Indeed, there is already good evidence that polyamines inhibit voltage-gated $\mathrm{Ca}^{2+}$ channels (Gomez and Hellstrand, 1995; Lasater and Solessio, 2002) and activate the G protein coupled, extracellular $\mathrm{Ca}^{2+}$-sensing receptor, CaR (Quinn et al., 1997).

\footnotetext{
* Corresponding author. Tel.: +44 113233 4236; fax: +44 1132334228.

E-mail addresses: rocher@ibgm.uva.es (A. Rocher), kemp@cf.ac.uk (P.J. Kemp).
}

The principal mammalian arterial chemoreceptor is the carotid body (Gonzalez et al., 1994). During periods of reduced $\mathrm{O}_{2}$ availability, the type I (or glomus) cells of the carotid body release neurotransmitters onto the terminals of the carotid sinus nerve, evoking increased afferent traffic to the brain stem from the carotid sinus nerve which results in a reflex hyperventilatory response (Gonzalez et al., 1992). Whilst a wide variety of molecular mechanisms have been proposed to underlie the response of glomus cells to hypoxia (Kemp and Peers, 2007, 2009), they all converge onto an increase in intracellular $\mathrm{Ca}^{2+}$ concentration via activation of voltage-dependent $\mathrm{Ca}^{2+}$ channels (Buckler and Vaughan-Jones, 1994), a prerequisite for neurotransmitter release (Conde et al., 2007; Lopez-Barneo et al., 2001). Since polyamines have been shown to be stored at high concentration in neurotransmitter vesicles (Masuko et al., 2003), and $\mathrm{Ca}^{2+}$ influx (rather than release of $\mathrm{Ca}^{2+}$ from intracellular stores (Gonzalez et al., 1993; Vicario et al., 2000)) is crucial to the $\mathrm{O}_{2}$ sensing pathway of the carotid body, we postulated that extracellular polyamines (in particular, spermine) may play a role in the modulation of the response of carotid body glomus to hypoxia. Therefore, the first aim of this study was to determine the expression profiles of known targets for spermine action, namely voltage-gated $\mathrm{Ca}^{2+}$ channels (Gomez and Hellstrand, 1995; Lasater and Solessio, 2002) and CaR (Chattopadhyay et al., 1997; Wang et al., 2003), in the adult rat carotid body. Secondly, in order to examine the possibility that spermine might modulate carotid body function, the ability of spermine to regulate hypoxia- and depolarization-evoked catecholamine release from isolated carotid bodies was tested. Finally, the effects of spermine 
on recombinant L-type $\mathrm{Ca}^{2+}$ channel activity and hypoxia-induced $\mathrm{Ca}^{2+}$ influx into isolated glomus cells were investigated in order to determine the molecular mechanisms responsible for extracellular spermine regulation of carotid body function. Some of these data were presented in preliminary form at the International Society for Arterial Chemoreceptors, Valladolid, Spain in July 2008 (Cayzac et al., 2009).

\section{Materials and methods}

\subsection{Experiments employing adult rat carotid body}

Male Wistar rats (100-350 g) were deeply anaesthetized with sodium pentobarbitone $\left(60 \mathrm{mg} \mathrm{kg}^{-1}\right.$; I.P.), according to U.K. Home Office regulations, and were then subjected to the following experimental procedures: (i) reverse transcription followed by PCR (RT-PCR) of mRNA isolated from whole carotid bodies; (ii) immunohistochemistry on thin carotid body sections; (iii) neurotransmitter release from intact carotid bodies; (iv) $\mathrm{Ca}^{2+}$ imaging in isolated glomus cells.

\subsubsection{RT-PCR of mRNA isolated from whole carotid bodies}

The carotid bifurcations were resected, the carotid bodies were identified, cleaned of surrounding connective tissue under a dissecting microscope, and total RNA was extracted from six carotid bodies using RNeasy Micro kit (Qiagen, Crawley, Surry, U.K.) according to the manufacturer's instructions. As positive controls for calcium channel amplification, total RNA was extracted from eye and brain using Trizol (Invitrogen, Paisley, Strathclyde, U.K.) according to the manufacturer's instructions. $1 \mu \mathrm{g}$ of total RNA was reverse-transcribed at $50^{\circ} \mathrm{C}$ for $30 \mathrm{~min}$ using Superscript III (Invitrogen, Paisley, Strathclyde, U.K.). $2 \mu$ l of cDNA were used for each PCR reaction using the Premix Ex-taq polymerase kit (Lonza, Basel, Switzerland) with intron-spanning primers $(4 \mu \mathrm{M})$ designed to amplify $\mathrm{Ca}_{\mathrm{V}} 1.2-1.3-1.4$ (L-type), $\mathrm{Ca}_{\mathrm{V}} 2.1$ (P/Q-type), $\mathrm{Ca}_{\mathrm{V}} 2.2$ (N-type), Cav2.3 (R-type), Cav3.1-3.2-3.3 (T-type) and CaR; see Table 1 . PCR was carried out for 35 cycles of 1 min denaturation at $95^{\circ} \mathrm{C}, 1 \mathrm{~min}$ at the appropriate annealing temperature (see Table 1 ) and $1 \mathrm{~min}$ extension at $72^{\circ} \mathrm{C}$. All PCR products which were amplified from carotid body were fully sequenced to demonstrate the presence of bona fide transcripts for the genes of interest.

\subsubsection{Immunohistochemistry on thin carotid body sections}

After opening of the thoracic cavity, the tissue was cleared of blood and fixed in situ by transcardial perfusion through the left ventricle, using a peristaltic pump, sequentially with $50 \mathrm{~mL}$ of heparinized (10 units $\mathrm{mL}^{-1}$ ) phosphate-buffered saline (PBS) and at a rate of $8 \mathrm{~mL} \mathrm{~min}^{-1}$ and $100 \mathrm{~mL}$ of ice-cold fixative solution consisting of $4 \%(\mathrm{w} / \mathrm{v})$ paraformaldehyde (Sigma-Aldrich, Poole, Dorset, U.K.) in PBS at a rate of $20 \mathrm{~mL} \mathrm{~min}^{-1}$. The carotid bifurcations were then removed and placed in a $30 \%(\mathrm{w} / \mathrm{v}$ in PBS) sucrose solution for $24 \mathrm{~h}$. Following this incubation, the tissue was mechanically cleaned of connective tissue and fat before being frozen and embedded in OCT Tissue-Tek Compound (Sakura Finetek, Torrance, CA, U.S.A.). $4 \mu \mathrm{m}$ microtome sections were cut at $-25^{\circ} \mathrm{C}$ and placed onto Superfrost Plus microscope slides (VWR International, Lutterworth, Leicestershire, U.K.). Sections were permeabilised using sodium dodecyl sulfate ( $1 \%(\mathrm{w} / \mathrm{v})$ in PBS) for $5 \mathrm{~min}$ and then twice washed in PBS before being incubated for $1 \mathrm{~h}$ in PBS containing 5\% Seablock (Eastcoast Stratech Scientific, Soham, Suffolk, U.K.). Sections were then incubated overnight at $4{ }^{\circ} \mathrm{C}$ with an appropriate selection of the following primary antibodies: Cav1.2 (1/200; Alomone, Buckingham, Bucks, U.K.), Ca 1.3 (1/200; Sigma-Aldrich, Poole, Dorset, U.K.), Cav2.1 (1/200; Alomone, Buckingham, Bucks, U.K.), Cav2.2 (1/100; Alomone, Buckingham, Bucks, U.K.), Cav2.3
(1/200; Santa Cruz, Heidelberg, Germany), tyrosine hydroxylase (1/1000; Sigma-Aldrich, Poole, Dorset, U.K.) and CaR (1/200; US Biological, Swampscott, MA, U.S.A.). Sections were then washed 3 times in PBS before being incubated for $1 \mathrm{~h}$ with Alexa 594- and FITC-conjugated secondary antibodies (1/1000; Invitrogen (Molecular Probes), Paisley, Strathclyde, U.K.) for $1 \mathrm{~h}$ at room temperature. The sections were again washed thrice with PBS and mounted using Vectashield, containing DAPI (Vectorlabs, Servion, Switzerland), before being viewed with a standard fluorescence or confocal microscope. Negative controls consisted either of omitting the primary antibodies from the first incubation or by pre-incubating the primary antibodies with their antigenic peptides (where available). These negative controls resulted in no staining (not shown).

\subsubsection{Neurotransmitter release from intact carotid bodies}

This technique has been extensively described elsewhere (e.g. Conde et al., 2007; Rocher et al., 2009). Briefly, the catecholamine store of intact carotid bodies was radiolabelled by a $2 \mathrm{~h}$ incubation with $30 \mu \mathrm{M}\left[{ }^{3} \mathrm{H}\right]$ tyrosine $\left(48 \mathrm{Ci} \mathrm{mmol}^{-1}\right), 100 \mu \mathrm{M}$ of 6 -methyltetrahydropterine and $1 \mathrm{mM}$ of ascorbic acid dissolved in a solution containing (in mM): $140 \mathrm{NaCl}, 5 \mathrm{KCl}, 2 \mathrm{CaCl}_{2}, 1.1 \mathrm{MgCl}_{2}, 5$ glucose, 10 HEPES, pH 7.4. Unincorporated $\left[{ }^{3} \mathrm{H}\right]$ tyrosine was removed by rinsing the carotid bodies in the same solution for $1 \mathrm{~h}$. Carotid bodies were individually incubated at $37^{\circ} \mathrm{C}$ in bicarbonate-buffered solution containing (in $\mathrm{mM}$ ): $116 \mathrm{NaCl}, 24 \mathrm{NaHCO}_{3}, 5 \mathrm{KCl}, 2 \mathrm{CaCl}_{2}$, $1.1 \mathrm{MgCl}_{2}, 5$ glucose, 10 HEPES, pH 7.4, equilibrated with $20 \% \mathrm{O}_{2}$, $5 \% \mathrm{CO}_{2}, 75 \% \mathrm{~N}_{2}$. The solutions used were bubbled either with $20 \%$ $\mathrm{O}_{2}, 5 \% \mathrm{CO}_{2}$ and $75 \% \mathrm{~N}_{2}$ (normoxia); or $7 \% \mathrm{O}_{2}, 5 \% \mathrm{CO}_{2}$ and $88 \%$ $\mathrm{N}_{2}$ (hypoxia). Where a "high potassium" solution was employed, $\mathrm{NaCl}$ and $\mathrm{KCl}$ concentrations were 86 and $35 \mathrm{mM}$, respectively. Spermine $(500 \mu \mathrm{M})$ and $\mathrm{R}-568(100 \mathrm{nM})$, the latter prepared as a $10 \mathrm{mM}$ stock solution in dimethyl sulfoxide), were diluted in the bicarbonate-buffered solution. Every $10 \mathrm{~min}$, the bathing solution was collected and replaced by fresh solution. A solution containing ascorbic and acetic acid was added to each collected sample before the $\left[{ }^{3} \mathrm{H}\right]$-catecholamines were absorbed with alumina. The alumina was then washed extensively and eluted with $1 \mathrm{~N} \mathrm{HCl}$ before the $\left[{ }^{3} \mathrm{H}\right]$-catecholamine was quantified by liquid scintillation counting. Quantitation of the effect of spermine on the evoked release was achieved by calculating the ratio of the second hypoxic response (HOX2) to the first hypoxic response (HOX1) for each individual carotid body preparation $(\mathrm{N})$, and these data were plotted as the mean ( \pm S.E.M.) of HOX2/HOX1 values (see, for example, Conde et al., 2007).

\subsection{4. $\mathrm{Ca}^{2+}$ imaging in isolated glomus cells.}

The carotid artery bifurcations were excised, carotid bodies dissected and placed in ice-cold solution containing (in $\mathrm{mM}$ ): $143 \mathrm{NaCl}, 2 \mathrm{KCl}, 2 \mathrm{CaCl}_{2}, 1.1 \mathrm{MgCl}_{2}, 5.5$ glucose and $10 \mathrm{~N}-2-$ hydroxyethylpiperazine- $\mathrm{N}^{\prime}$-2-ethanesulfonic acid (HEPES), pH 7.4, bubbled with $100 \% \mathrm{O}_{2}$. Isolated carotid bodies were incubated for $15 \mathrm{~min}$ at $37^{\circ} \mathrm{C}$ in a solution (as above, but without $\mathrm{Mg}^{2+}$ and $\left.\mathrm{Ca}^{2+}\right)$ containing type IV collagenase $\left(2.5 \mathrm{mg} \mathrm{mL}^{-1}\right.$-Sigma-Aldrich, Poole, Dorset, U.K.) and bovine serum albumin (BSA; $6 \mathrm{mg} \mathrm{mL}^{-1}$ -Sigma-Aldrich, Poole, Dorset, U.K.). Following initial incubation, the carotid bodies were transferred to a $\mathrm{Mg}^{2+}$ - and $\mathrm{Ca}^{2+}$-free solution containing trypsin $\left(1 \mathrm{mg} \mathrm{mL}^{-1}\right)$ and BSA $\left(6 \mathrm{mg} \mathrm{mL}^{-1}\right)$ and were incubated for a further $20 \mathrm{~min}$ at $37^{\circ} \mathrm{C}$. The carotid bodies were then transferred to F-10/Dulbecco's modified Eagle's medium (F-10/DMEM) supplemented with $10 \%$ fetal calf serum, $1 \%(\mathrm{v} / \mathrm{v}$ ) antibiotic (penicillin \& streptomycin)/antimycotic, $2 \mathrm{mM}$ L-glutamine (all from Gibco-BRL, Paisley, Strathclyde, U.K.), gently triturated and centrifuged at $150 \times \mathrm{g}$ for $4 \mathrm{~min}$. The cell pellet was resuspended in $50 \mu \mathrm{L}$ of supplemented F-10/DMEM, the cells seeded onto poly-L-lysine treated $\left(0.1 \mathrm{mg} \mathrm{mL}^{-1}\right)$ glass coverslips and allowed to adhere for $50 \mathrm{~min}$ before the addition of $2 \mathrm{~mL}$ of 
Table 1

Primers employed for the RT-PCR reactions.

\begin{tabular}{|c|c|c|c|c|c|}
\hline Gene bank & mRNA & Primer sequences $5^{\prime}-3^{\prime}$ & CG\% & $\mathrm{Tm} /{ }^{\circ} \mathrm{C}$ & Amplicon size, bp \\
\hline \multirow[t]{4}{*}{ AF110178 } & $\mathrm{CaR}$ & $\mathrm{F}_{1}:$ ACCTGCTTACCCGGAAGAGGGCTTT & 56 & 56.0 & 586 \\
\hline & & $\mathrm{R}_{1}$ : GCACAAAGGCGGTCAGGAAAATGCC & 56 & & \\
\hline & & $\mathrm{F}_{2}:$ CTGCTTTGAGTGTGTGGAGT & 50 & 62.5 & 759 \\
\hline & & $\mathrm{R}_{2}$ : GAAGATGAGCATGCTGAAGG & 50 & & \\
\hline \multirow[t]{2}{*}{ NM_012517 } & $\mathrm{Ca}_{\mathrm{v}} 1.2$ (L-type) & F: GGAGCCCGAGATGCCTGTG & 68 & 58.3 & 433 \\
\hline & & R: AACGTTGATCGCGCTGGACTGAA & 52 & & \\
\hline \multirow[t]{2}{*}{ NM017298 } & $\mathrm{Ca}_{\mathrm{v}} 1.3$ (L-type) & F: CTGCCCGTGCCCTCTTCTGTTTAT & 54 & 56.5 & 512 \\
\hline & & R: GAGGAGGGGGACCATGGCTTTTAT & 54 & & \\
\hline \multirow[t]{2}{*}{ DQ393415 } & $\mathrm{Ca}_{\mathrm{v}} 1.4$ (L-type) & F: CCGCCGGGCAGTCAAGT & 71 & 58.5 & 531 \\
\hline & & R: TGGGGGAAGGTATCAAAGGTG & 52 & & \\
\hline \multirow[t]{2}{*}{ NM012918 } & $\mathrm{Ca}_{\mathrm{v}} 2.1 \mathrm{P} / \mathrm{Q}$-type) & F: GACACGGCCTTACTTCCACTCTT & 52 & 58.0 & 576 \\
\hline & & R: GCTGCCTCTTCCTCTTCTTGTTC & 55 & & \\
\hline \multirow[t]{2}{*}{ NM147141 } & $\mathrm{Ca}_{\mathrm{v}} 2.2$ (N-type) & F: CCCGTGCGGACCGACTCATT & 74 & 59.3 & 504 \\
\hline & & R: CCTTGGCTGGGCTTCTACCT & 67 & & \\
\hline \multirow[t]{2}{*}{ NM019294 } & $\mathrm{Ca}_{\mathrm{v}} 2.3$ (R-type) & F: TACAATACCAATGATGCCTTA & 38 & 55.0 & 696 \\
\hline & & R: GACCCCAAAATCAAAGCAGT & 44 & & \\
\hline \multirow[t]{2}{*}{ NM031601 } & $\mathrm{Ca}_{\mathrm{v}} 3.1$ (T-type) & F GGGCGGCGTGAGGAGAAGCGACTAC & 67 & 61.0 & 425 \\
\hline & & R: GGGGTTGATGGGCAGCGACAGATT & 58 & & \\
\hline \multirow[t]{2}{*}{ AF290213 } & $\mathrm{Ca}_{\mathrm{v}} 3.2$ (T-type) & F: TCGGCGCCGGGAGGAGAAAC & 70 & 61.6 & 420 \\
\hline & & R: ATGCGGATGATGGTGGGATTGATG & 50 & & \\
\hline \multirow[t]{3}{*}{ AF290214 } & $\mathrm{Ca}_{\mathrm{v}} 3.3$ (T-type) & F: GCGACCGCGGGGAGGACGAG & 80 & 61.7 & 485 \\
\hline & & R: AGGACCCGGAGGACCCCCAGAATC & 67 & & \\
\hline & & R: GCATTCCCATCCCTCTCCTCAAA & 62 & & \\
\hline
\end{tabular}

culture medium to each of the dishes. Before being used for $\mathrm{Ca}^{2+}$ imaging, cells were cultured for $16-24 \mathrm{~h}$ in a humidified incubator gassed with $5 \% \mathrm{CO}_{2} / 95 \%$ air. Glomus cells were loaded with $4 \mu \mathrm{M}$ fura-2 AM for $40 \mathrm{~min}$ in a HEPES-buffered solution containing (in mM): $125 \mathrm{NaCl}, 4 \mathrm{KCl}, 1 \mathrm{CaCl}_{2}, 1 \mathrm{MgSO}_{4}, 1 \mathrm{NaH}_{2} \mathrm{PO}_{4}, 20$ HEPES, 6 glucose (pH 7.4) supplemented with $0.1 \%(\mathrm{w} / \mathrm{v}) \mathrm{BSA}$ and then washed for $15 \mathrm{~min}$ in HEPES-buffered physiological solution to be used for the experiments, which contained (in $\mathrm{mM}$ ): $125 \mathrm{NaCl}$, $5 \mathrm{KCl}, 0.5$ or 1.2 the influx via $\mathrm{CaCl}_{2}, 0.5 \mathrm{MgCl}_{2}, 5$ HEPES and 10 glucose, $\mathrm{pH}$ 7.4. For the "high potassium solution", $\mathrm{NaCl}$ was lowered to $115 \mathrm{mM}$ and $\mathrm{KCl}$ increased to $15 \mathrm{mM}$. All the recordings were performed at $26 \pm 1{ }^{\circ} \mathrm{C}$. Individual glomus cells were identified by post hoc immunostaining using a tyrosine hydroxylase antibody (see Fig. 5F). In some experiments, temperature and $\mathrm{PO}_{2}$ were measured in real-time using a microthermister and polarized carbon fibre electrode (Mojet et al., 1997), respectively. Data are presented as 340/380 values with the number of individual cells $(n)$ and the number of cell isolations $(N)$ indicated in the legends.

\subsection{Experiments employing recombinant ion channels expressed in HEK 293 cells}

\subsubsection{HEK 293 cell culture}

Wild type HEK 293 cells and HEK 293 cells that stably express either the human $\mathrm{BK}_{\mathrm{Ca}} \alpha$ subunit (KCNMA1; accession number, NM_002247, see Telezhkin et al., 2010) or the human Cav1.2 (Accession number, AF465484, see Scragg et al., 2008), were grown in Earle's minimal essential medium containing $10 \%$ fetal calf serum, $100 \mathrm{U} \mathrm{mL}^{-1}$ penicillin G, $100 \mu \mathrm{g} \mathrm{mL}^{-1}$ streptomycin sulfate, $1 \% \mathrm{~L}-$ glutamine, $1 \mathrm{mg} \mathrm{mL}^{-1}$ G418 sulfate (all from Invitrogen, Paisley, Strathclyde, U.K.) in a humidified incubator gassed with $5 \% \mathrm{CO}_{2} / 95 \%$ air. HEK 293 cells were passaged every 5-7 days in a ratio 1:9 using $\mathrm{Ca}^{2+}$ - and $\mathrm{Mg}^{2+}$-free PBS.

\subsubsection{Whole-cell recordings of $\mathrm{Ca}_{v} 1.2-\mathrm{HEK} 293$ cells}

HEK 293 cells stably expressing L-type $\mathrm{Ca}_{\mathrm{v}} 1.2 \mathrm{Ca}^{2+}$ channels $\left(\mathrm{Ca}_{\mathrm{v}} 1.2\right.$-HEK 293) were a gift from Prof. C. Peers (University of Leeds, West Yorkshire, U.K.); wild type HEK 293 cells do not express functional, voltage-activated L-type $\mathrm{Ca}^{2+}$ channels (Fearon et al., 1997). Cells attached to glass coverslips were placed in a continuously perfused $\left(5 \mathrm{~mL} \mathrm{~min}{ }^{-1}\right)$ recording chamber (volume ca.
$200 \mu \mathrm{L}$ ) mounted on the stage of an inverted microscope equipped with phase-contrast optics. Bath solution contained (in mM): 135 $\mathrm{NaCl}, 5 \mathrm{KCl}, 1.2 \mathrm{CaCl}_{2}, 1.2 \mathrm{MgCl}_{2}, 5$ HEPES and 10 glucose, pH 7.4. Pipette solution contained (mM): $120 \mathrm{CsCl}_{2}, 20$ TEA-Cl, $2 \mathrm{MgCl}_{2}, 10$ EGTA, 10 HEPES, 2 Na-ATP, pH 7.2 with $\mathrm{CsOH}$. After the whole-cell configuration had been achieved, the bath solution was changed to a solution containing (in $\mathrm{mM}$ ): $113 \mathrm{NaCl}, 5 \mathrm{CsCl}, 0.6 \mathrm{MgCl}_{2}, 1.2 \mathrm{CaCl}_{2}$, $2 \mathrm{BaCl}_{2}, 5$ HEPES, 10 glucose and 20 TEA-Cl, pH 7.4. $\mathrm{Cs}^{+}$and TEA ${ }^{+}$ were employed to block $\mathrm{K}^{+}$channels and $\mathrm{Ba}^{2+}$ was employed as the charge carrier since it is more permeant than $\mathrm{Ca}^{2+}$ and its currents do not inactivate rapidly. Spermine, R-568 and nifedipine were diluted in this $\mathrm{Ba}^{2+}$-containing solution and applied extracellularly where indicated in text and figure legends. Cells were voltageclamped at $-70 \mathrm{mV}$ and then ramped at $0.1 \mathrm{~Hz}$ from $-100 \mathrm{mV}$ to $+100 \mathrm{mV}$ for $200 \mathrm{~ms}$ before being stepped from $-80 \mathrm{mV}$ to $+15 \mathrm{mV}$ for $50 \mathrm{~ms}$.

\subsubsection{Whole-cell recordings of BK $\alpha$ HEK 293 cells}

The bath solution contained (in $\mathrm{mM}$ ): $135 \mathrm{NaCl}, 5 \mathrm{KCl}, 1.2 \mathrm{CaCl}_{2}$, $1.2 \mathrm{MgCl}_{2}, 5$ HEPES and 10 glucose, $\mathrm{pH}$ 7.4. The pipette solution was composed of (in $\mathrm{mM}$ ): $10 \mathrm{NaCl}, 117 \mathrm{KCl}, 2 \mathrm{MgCl}_{2}, 11$ HEPES, pH 7.2; for the bath solution, free $\left[\mathrm{Ca}^{2+}\right]$ was adjusted to $300 \mathrm{nM}$ using ethylene-glycol-tetra-acetic acid (EGTA), as calculated by Maxchelator (http://maxchelator.stanford.edu). Cells were voltage-clamped at $-70 \mathrm{mV}$ and currents were evoked in the whole cell configuration by a $1 \mathrm{~s}$ voltage-ramp from $120 \mathrm{mV}$ to $+60 \mathrm{mV}$ repeated at $0.05 \mathrm{~Hz}$.

All electrophysiology experiments ( $\mathrm{K}^{+}$and $\mathrm{Ca}^{2+}$ currents) were conducted at ambient room temperature, and currents were leak-subtracted off-line. Current recordings were made using an Axopatch 200A amplifier and Digidata 1320 A/D interface (Axon Instruments, Forster City, CA, U.S.A.). All currents were digitized at $10 \mathrm{kHz}$ and Bessel low-pass filtered at $5 \mathrm{kHz}$. Unless stated otherwise, all statistical comparisons were made using a Student's paired $t$-test.

\section{Results}

Using RT-PCR, mRNAs encoding all of the voltage-activated $\mathrm{Ca}^{2+}$ channel $\alpha$-subunits could be amplified from either adult rat brain or adult rat eye, as expected (Fig. 1). However, only $\mathrm{Ca}_{\mathrm{v}} 1.2\left(\alpha_{1 \mathrm{C}}\right.$ L-type $\mathrm{Ca}^{2+}$ channel) and $\mathrm{Ca}_{\mathrm{v}} 2.2\left(\mathrm{~N}\right.$-type $\mathrm{Ca}^{2+}$ channel) could be 

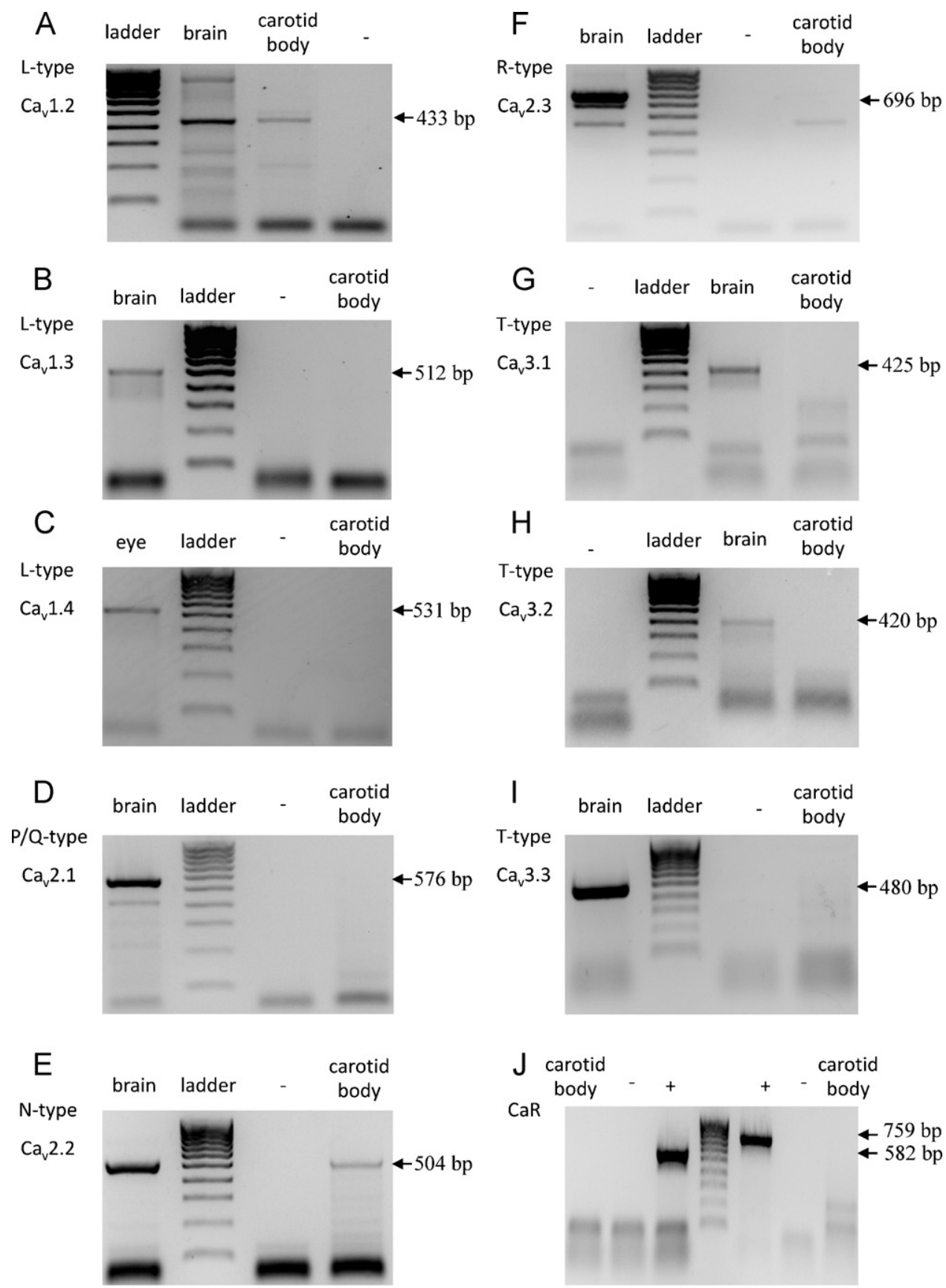

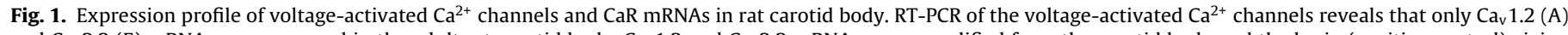

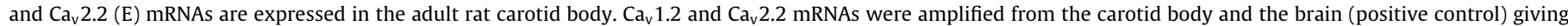

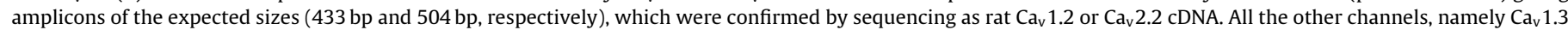

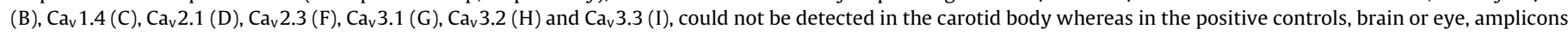

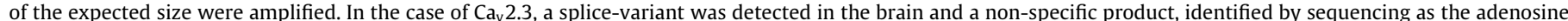

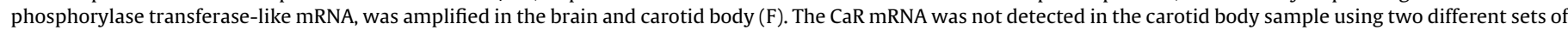

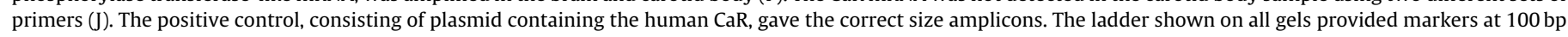
intervals.

amplified from carotid body RNA (Fig. 1A and E, respectively). No other L-type (Fig. 1B and C), nor P/Q (Fig. 1D), R-type (Fig. 1F) and T-type (Fig. $1 \mathrm{G}-\mathrm{I}$ ) $\mathrm{Ca}^{2+}$ channels could be amplified from carotid body cDNA. Using two separate primer pairs, CaR signal could also not be detected in carotid body (Fig. 1J).

Consistent with the mRNA studies, immunohistochemistry demonstrated that both $\mathrm{Ca}_{\mathrm{v}} 1.2$ (green-Fig. 2A) and $\mathrm{Ca}_{\mathrm{v}} 2.2$ (green-Fig. 2D) were detected in type 1, tyrosine hydoxylasepositive (red-Fig. $2 \mathrm{~B}$ and $\mathrm{E}$ ) cells. In addition, $\mathrm{Ca}_{\mathrm{v}} 1.2$ was also expressed in the nerve fibres (arrows-Fig. 2C). Although CaR could not be amplified by RT-PCR in the carotid body, immunohistochemistry revealed that the receptor protein was expressed in the nerve terminals (green-Fig. 2G and I). This pattern of CaR expression has also been observed elsewhere in the adult (Ruat et al., 1995) and developing (Vizard et al., 2008) brain. The lack of CaR PCR products from carotid body mRNA is consistent with the idea that receptor transcripts are predominantly expressed in the soma of the petrosal ganglion neurons (which are not present in mRNA isolated from the carotid body itself), whilst the receptor protein is also expressed in the nerve endings. 

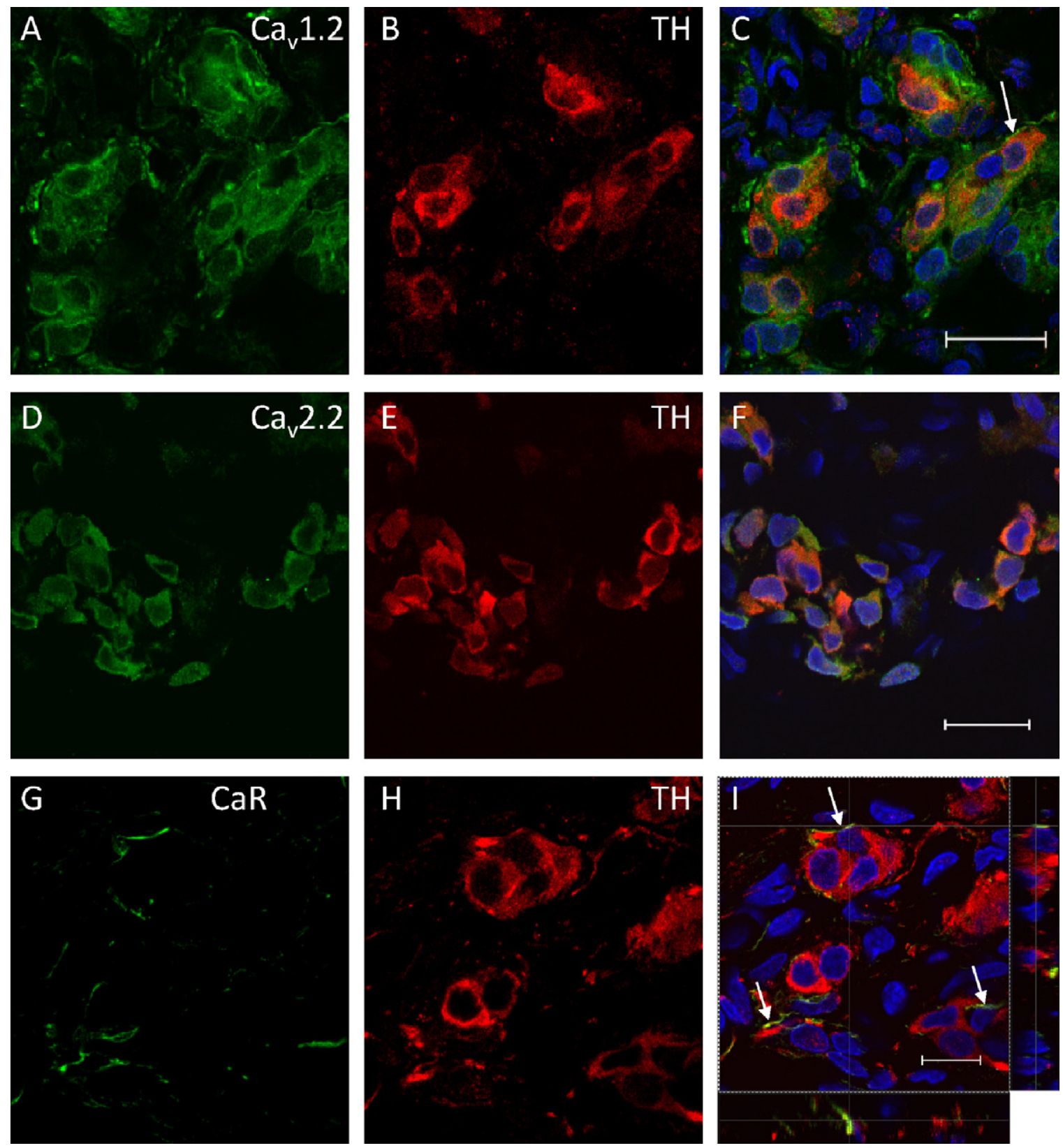

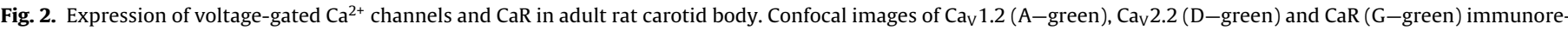

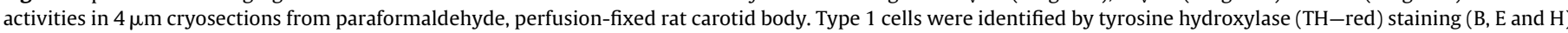

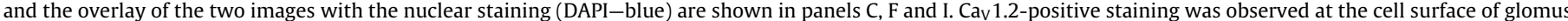

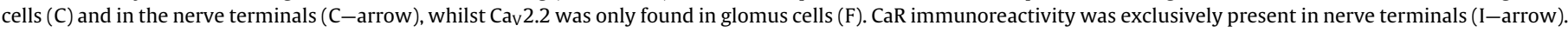

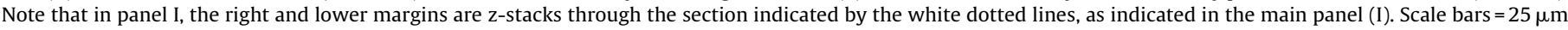
(C and F) and $10 \mu \mathrm{m}(\mathrm{I})$.

Measurement of neurotransmitter release from isolated carotid bodies in vitro showed that application of $500 \mu \mathrm{M}$ spermine did not affect baseline catecholamine secretion (Fig. 3A), but dramatically inhibited the hypoxia-evoked release (HOX2 versus HOX1). Indeed, spermine significantly decreased the HOX2/HOX1 ratio by $55 \%$ ( $p<0.01, n=6-$ Fig. $3 \mathrm{~A}$ and $\mathrm{B}$ ). Moreover, spermine inhibited the depolarization-evoked (using $35 \mathrm{mM} \mathrm{KCl}$ ) catecholamine release by $60 \%$ ( $p<0.01, n=6-$ not shown), indicating that the $\mathrm{O}_{2}$ sensing mechanism was not affected per se. In contrast to the inhibitory effect of spermine, $100 \mathrm{nM} \mathrm{R}-568$ (a concentration of this CaR-positive allosteric modulator which is known to promote $\mathrm{CaR}$ activation (Finney et al., 2008)), was unable to effect significantly the hypoxia-evoked catecholamine secretion from the carotid body (Fig. $4 \mathrm{~A}$ and $\mathrm{B}, n=6$ ).
As catecholamine secretion by the carotid body is mediated by, and strictly dependent upon, a rise in $\left[\mathrm{Ca}^{2+}\right]_{\mathrm{i}}$ (Gonzalez et al., 1994), the effect of spermine on $\left[\mathrm{Ca}^{2+}\right]_{i}$ homeostasis was investigated directly in isolated, tyrosine hydroxylase-positive glomus cells (see Fig. 5F). Since spermine is a known activator of CaR (Chattopadhyay et al., 1997), the effect of selective activation of CaR was also tested. Spermine had no effect on baseline 340/380 values (Fig. 5A). However, it was a potent inhibitor of depolarization-evoked $\mathrm{Ca}^{2+}$ influx (Fig. 5A and C); at $200 \mu \mathrm{M}$, spermine inhibited the $\mathrm{Ca}^{2+}$ influx induced by high external $\mathrm{K}^{+}$by $34 \%(p<0.01, N=5-$ Fig. $5 \mathrm{~A}$ and $C)$. The inhibition was concentration-dependent with a mean $\mathrm{IC}_{50}$ value of $473 \pm 70 \mu \mathrm{M}$ and a mean Hill coefficient of 0.84 (Fig. 5E, $n=17, N=3)$; these data were fitted with the maximal inhibition unfixed since spermine is not soluble at concentrations exceed- 
A

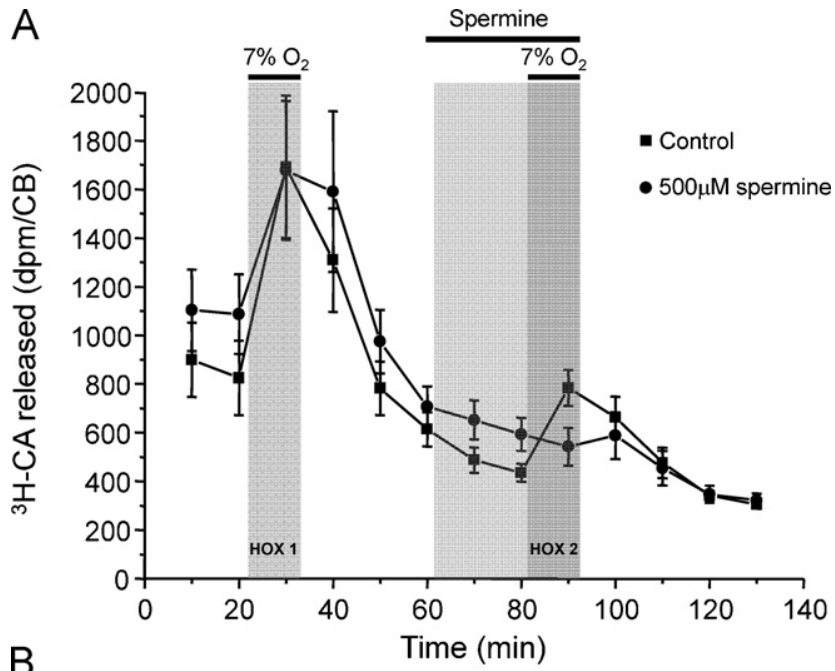

B

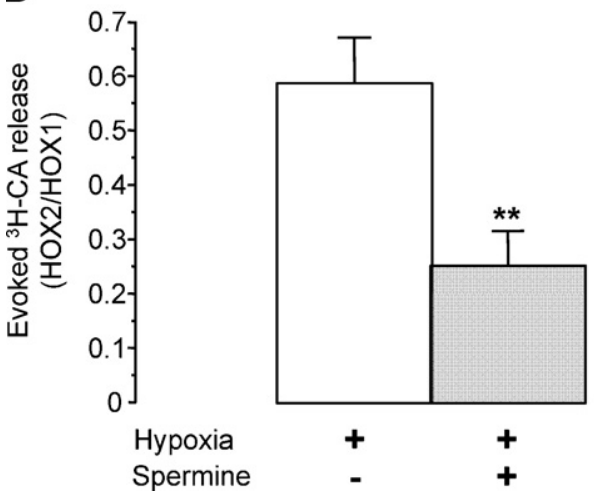

Fig. 3. Inhibitory effect of spermine on hypoxia-evoked catecholamine secretion from isolated carotid bodies. Mean $( \pm$ S.E.M.) time-courses of tritiated catecholamine $\left({ }^{3} \mathrm{H}-\mathrm{CA}\right)$ secretion induced by bubbling with $7 \% \mathrm{O}_{2}$ in the absence (squares) or presence (circles) of $500 \mu \mathrm{M}$ spermine $(\mathrm{A})$. The mean ( \pm S.E.M) catecholamine secretion induced by $7 \% \mathrm{O}_{2}$ from 6 separate carotid body preparations in the presence of $500 \mu \mathrm{M}$ spermine was significantly $\left({ }^{* *} p<0.01\right)$ different from that evoked by hypoxia in its absence (B).

ing those used in this study. The CaR positive allosteric modulator, $\mathrm{R}-568$, did not induce an increase in $\left[\mathrm{Ca}^{2+}\right]_{i}$ alone (Fig. 5B), nor did it significantly affect $\mathrm{Ca}^{2+}$ influx induced by high $\mathrm{K}^{+}(p>0.5$, $n=4$-Fig. $5 \mathrm{~B}$ and $\mathrm{D}$ ). Together with the molecular observations described in Figs. 1 and 2, these experiments strongly suggest that the targets of the inhibitory action of spermine observed in Fig. 3 are voltage-dependent $\mathrm{Ca}^{2+}$ channels.

Since $60-80 \%$ of the hypoxia-evoked $\mathrm{Ca}^{2+}$ influx into glomus cells is mediated by L-type $\mathrm{Ca}^{2+}$ channels (Silva and Lewis, 1995), the effect of spermine on the only L-type channel which could be detected in glomus cells, namely $\mathrm{Ca}_{\mathrm{V}} 1.2$ (Figs. 1 and 2), was determined directly using recombinant $\mathrm{Ca}_{\mathrm{V}} 1.2$ heterologously expressed in HEK 293 cells. These recombinant $\mathrm{Ca}^{2+}$ currents did not "rundown" during the 5 min protocol (Fig. 6C). However, $300 \mu \mathrm{M}$ of spermine inhibited strongly and significantly the $\mathrm{Ca}_{\mathrm{v}} 1.2$ currents, by $53 \pm 5 \%$ (Fig. $6 \mathrm{~A}$ and C; $n=5, p<0.01$ ), but $100 \mathrm{nM}$ R568 was without affect (Fig. $6 \mathrm{~B}$ and $\mathrm{C} ; n=6$ ). In contrast to the inhibitory action of spermine on $\mathrm{Ca}^{2+}$ currents, this polyamine was unable to modulate recombinant $\mathrm{BK}_{\mathrm{Ca}}$ currents, at any test voltage (Fig. $6 \mathrm{D}, n=6$, $p>0.5$ ).

With the knowledge that spermine inhibits recombinant $\mathrm{Ca}_{\mathrm{V}} 1.2$ in physiological $\left[\mathrm{Ca}^{2+}\right]_{0}$, the final series of experiments was designed to test whether spermine suppresses the response of the carotid body to low $\mathrm{PO}_{2}$ by reducing hypoxia-evoked $\mathrm{Ca}^{2+}$ influx into glomus cells. Fig. 7A shows simultaneous recordings of fura2 fluorescence ratio, temperature and $\mathrm{PO}_{2}$. In the absence of an
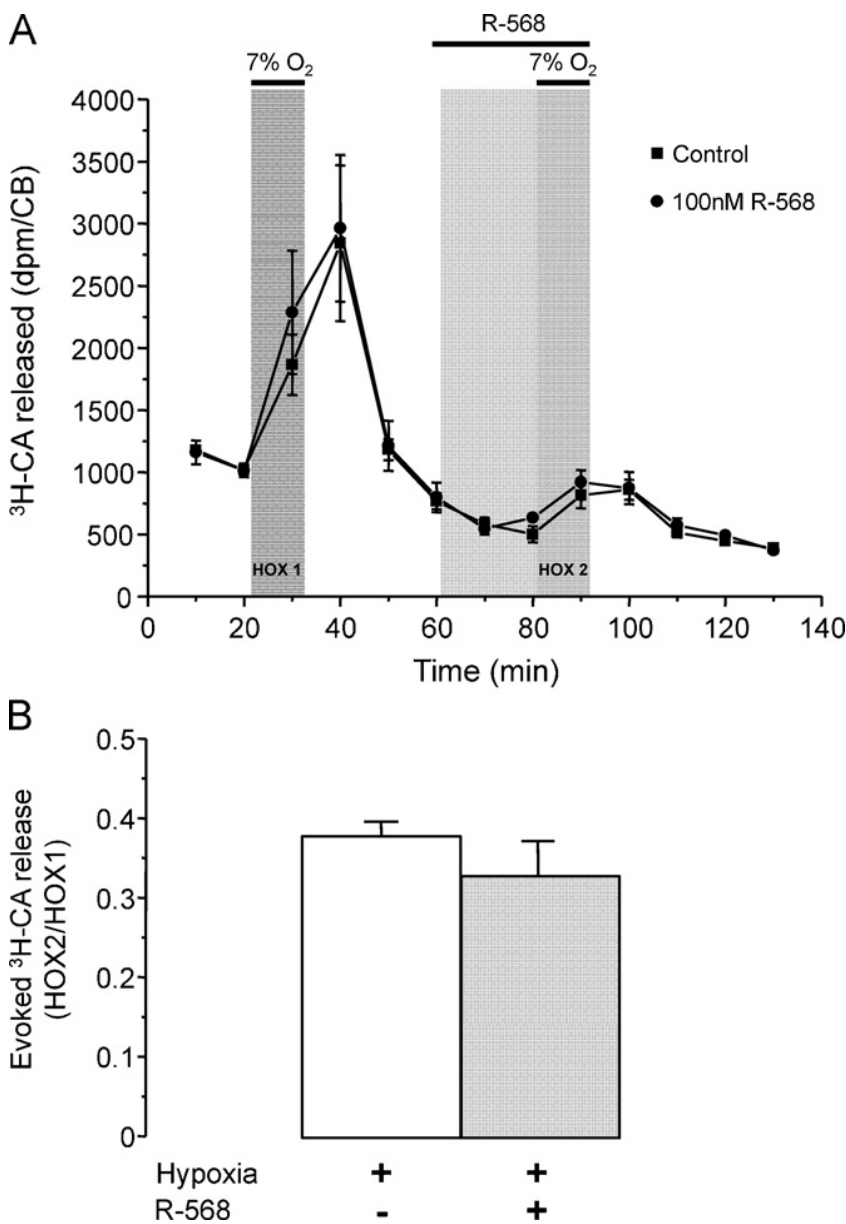

Fig. 4. Lack of effect of R-568 on hypoxia-evoked catecholamine secretion from isolated carotid bodies. Mean ( \pm S.E.M.) time-courses of tritiated catecholamine $\left({ }^{3} \mathrm{H}\right.$ CA) secretion induced by bubbling with $7 \% \mathrm{O}_{2}$ in the absence (black squares) or presence (red circles) of $100 \mathrm{nM}$ R-568 (A). The mean ( \pm S.E.M) catecholamine secretion induced by $7 \% \mathrm{O}_{2}$ from 6 separate carotid body preparations in the presence of 100 nM R-568 was not significantly $(p>0.1)$ different from that evoked by hypoxia in its absence (B). (For interpretation of the references to color in this figure legend, the reader is referred to the web version of the article.)

hypoxic stimulus, high $\mathrm{K}^{+}$induced a robust $\mathrm{Ca}^{2+}$ influx. Reductions in bath $\mathrm{PO}_{2}$ from $150 \mathrm{mmHg}$ to ca. $15 \mathrm{mmHg}$ evoked a rapid and reproducible $\mathrm{Ca}^{2+}$ influx. Importantly, bath co-application of $200 \mu \mathrm{M}$ spermine with hypoxia resulted in a significant reduction in the hypoxia-evoked $\mathrm{Ca}^{2+}$ influx, which was fully reversible upon removal of spermine from the bath (Fig. 7A). Indeed, spermine significantly inhibited the hypoxia-evoked $\mathrm{Ca}^{2+}$ influx by $41 \pm 12 \%$, (ANOVA with Tukey post hoc test, $p<0.05, n \geq 23, N \geq 3$, Fig. 7B) and the magnitude of this reduction was similar to that caused by spermine when $\mathrm{Ca}^{2+}$ influx was evoked by depolarization (see Fig. 5). To gain further insight into the effect of spermine on the chemoreception in type 1 cells, Fura- 2 ratio was plotted against $\mathrm{PO}_{2}$ and fitted to a single exponential $\left(y=y_{0}+A \mathrm{e}^{R x}\right.$, Fig. 7C); $\mathrm{PO}_{2}$ was measured on-line with the carbon fibre electrode, and Fig. 7C was constructed from data obtained during the transition from normoxia to full hypoxia. In absence and presence of $200 \mu \mathrm{M}$ spermine, the data fits generated the following parameters: $y=0.72+0.56 \mathrm{e}$ $-0.08 x$ (Hypoxia) and $y=0.72+0.18 \mathrm{e}^{-0.07 x}$ (Hypoxia plus spermine). As predicted from earlier data, spermine did not affect the baseline $\left[\mathrm{Ca}^{2+}\right]_{\mathrm{i}}\left(y_{\mathrm{b}}\right.$ is constant, $\left.p>0.05\right)$ or the sensitivity of the type 1 cells $(R$ is constant, $p>0.05$ ) but modified the amplitude of the response (A was significantly decreased upon application of spermine, $p<0.05$, $n=16, N=3)$. Taken together, these data show that spermine exerts an inhibitory influence on the carotid body's response to hypoxia, 

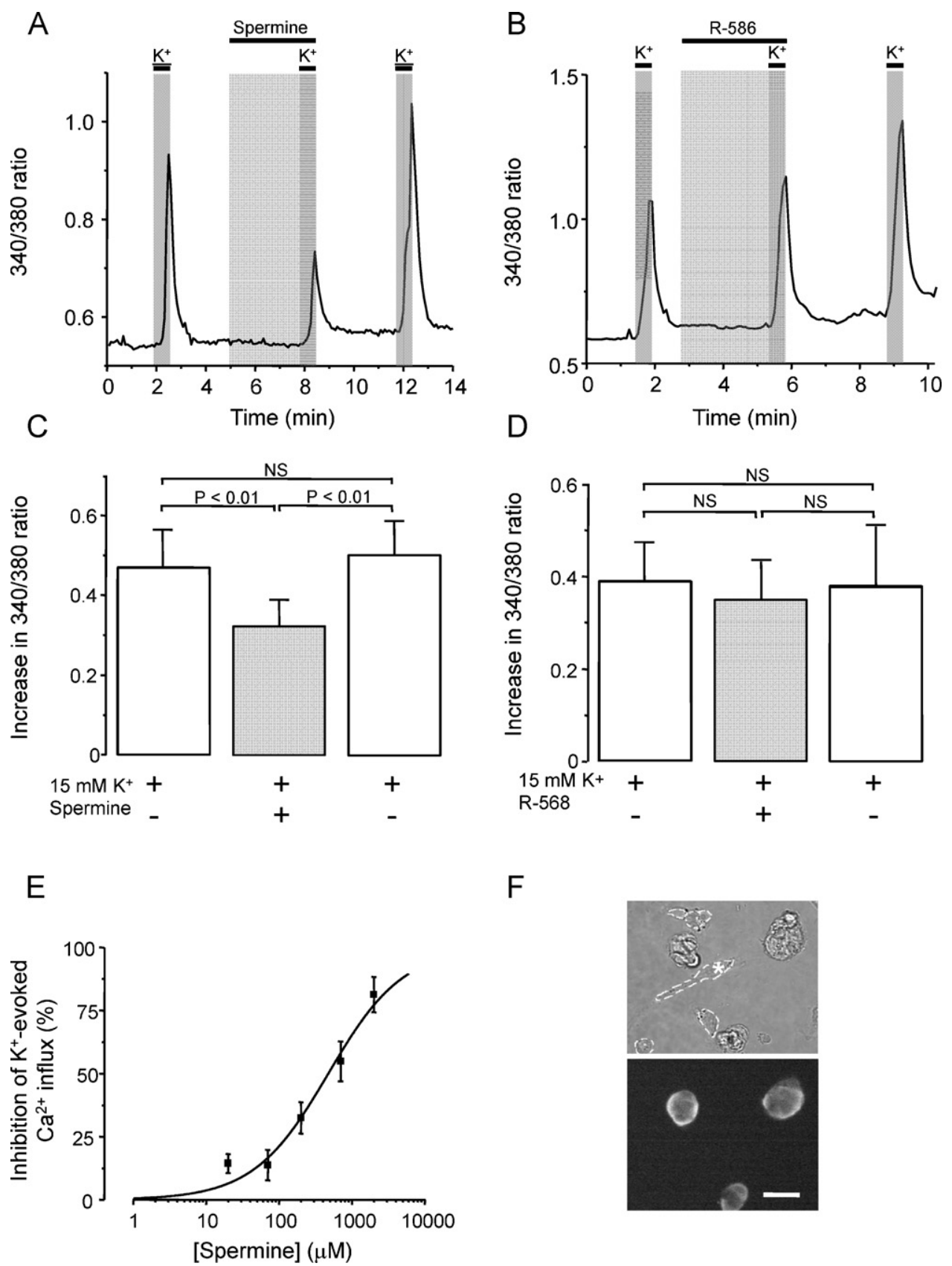

$\mathrm{F}$

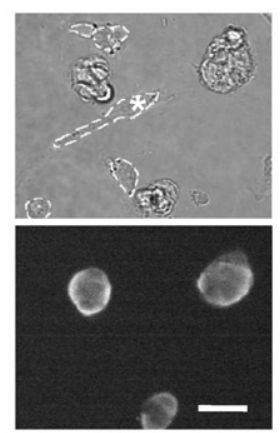

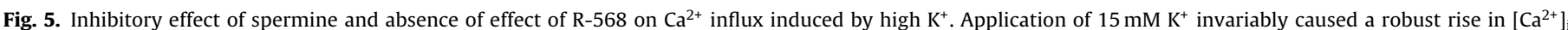

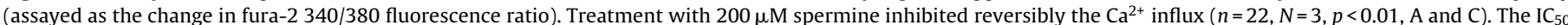

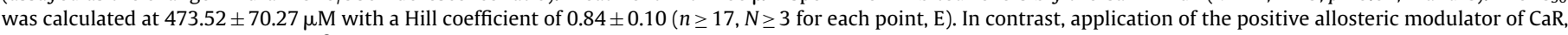

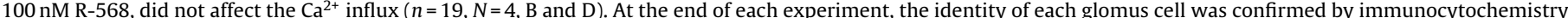

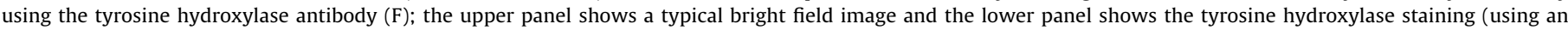

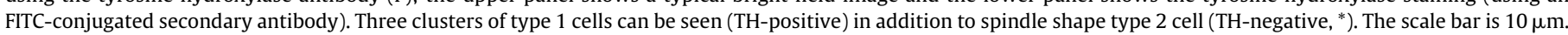

and that this effect is due, in the most part, to an inhibition of $\mathrm{Ca}_{\mathrm{v}} 1.2$ which is expressed in the glomus cells.

\section{Discussion}

Spermine is produced ubiquitously from L-arginine by the sequential actions of arginase, ornithine decarboxylase, spermidine synthase and spermine synthase (see (Persson, 2009)). Steadystate spermine concentration, which is a function of its rate of intracellular production and extracellular influx (Belting et al.,
2003) has been shown to be $400 \mu \mathrm{M}$ in smooth muscle cells (Sward et al., 1994). Within neurons, where it is co-packaged with neurotransmitters into vesicles, the synaptic vesicular spermine concentration may be as high as $2 \mathrm{mM}$ (Masuko et al., 2003). The rate-limiting step in the polyamine synthesis cascade is the conversion of ornithine to putrescine in mitochondria by orthithine decarboxylase. Tight regulation of the expression of this enzyme, which has an extremely short half-life, is absolutely pivotal in controlling the intracellular concentrations of polyamines, including spermine (Persson, 2009). There are a number of physiological and pathological states which increase cellular spermine content 

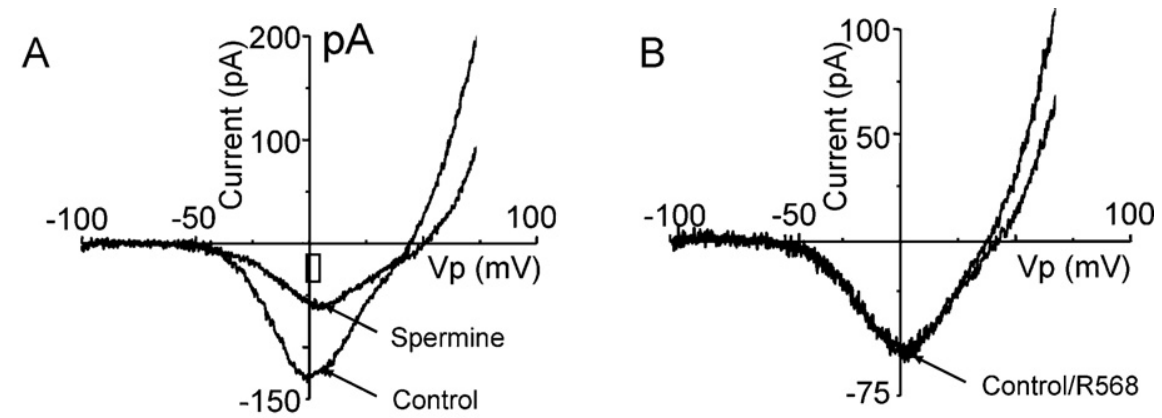

C
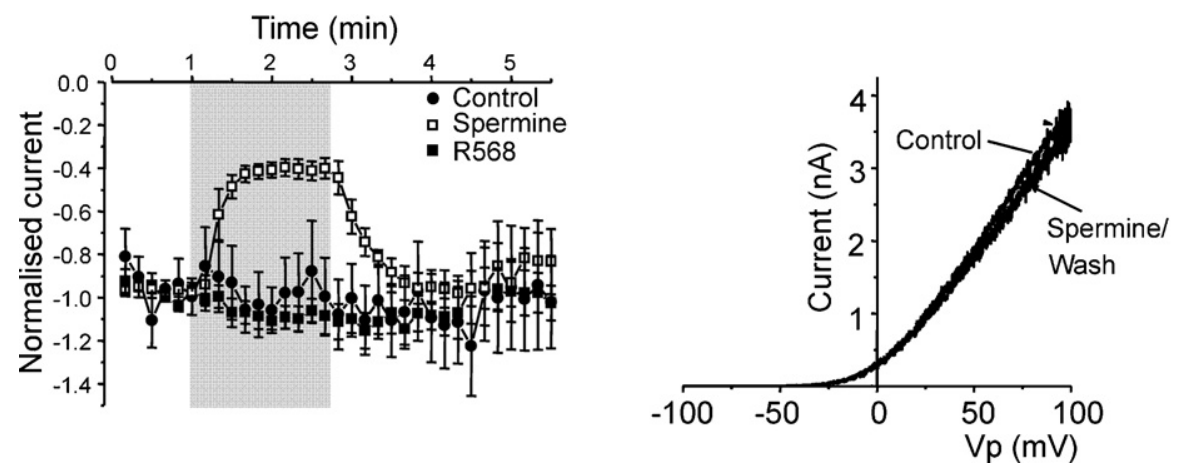

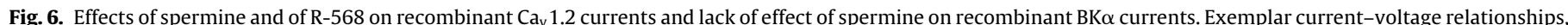

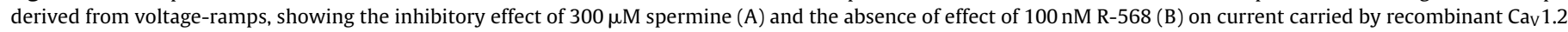

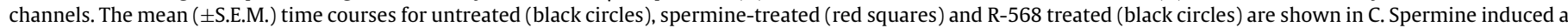

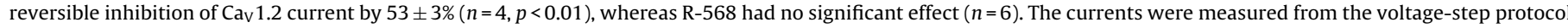

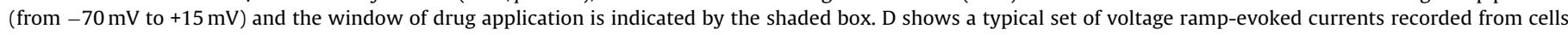

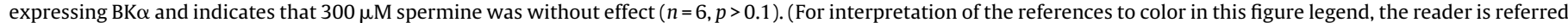
to the web version of the article.)

via stimulation of ornithine decarboxylase expression, including malignant transformation (Casero and Marton, 2007; Chaisiri et al., 1979), brain injury (Dogan et al., 1999a; Dogan et al., 1999b), or neuronal ischemia (Li et al., 2007). Importantly, there is accumulating evidence that chronic hypoxia increases polyamine concentrations, by a combination of increased production and/or uptake, in several physiological systems including the lung (Babal et al., 2002; Ruchko et al., 2003), heart (Tantini et al., 2006) and brain (Longo et al., 1993). Conversely, it has been recently shown, by gene chip array, that chronic hypoxia causes a decrease in ornithine decarboxylase mRNA in the carotid body (Ganfornina et al., 2005), suggesting that spermine levels in this tissue may be reduced in this pathological situation.

The data presented herein show that the predominant voltagegated $\mathrm{Ca}^{2+}$ channels which are expressed, at both the mRNA (Fig. 1) and the protein levels (Fig. 2), in the rat carotid body are of the Ltype $\left(\mathrm{Ca}_{\mathrm{V}} 1.2\right.$ or $\left.\alpha 1_{\mathrm{C}}\right)$ and $\mathrm{N}$-type $\left(\mathrm{Ca}_{\mathrm{V}} 2.2\right)$. These observations are broadly in line with other functional and molecular data obtained in this species (Caceres et al., 2009; Silva and Lewis, 1995), although Ttype ( $\mathrm{Ca}_{\mathrm{V}} 3.1$ ) channel mRNA expression has been reported (Caceres et al., 2009). Interestingly, even though carotid body glomus cells are of neuroendocrine origin, they do not express the $\mathrm{Ca}_{\mathrm{V}} 1.3$ (or $\alpha 1_{D}$ ) channel type most usually observed in neurons. Spermine has been reported to inhibit voltage-dependent $\mathrm{Ca}^{2+}$ channels in several cell types, including intestinal smooth muscle (Gomez and Hellstrand, 1995), hippocampus (Eterovic et al., 1997) and retina. Here we demonstrate that human recombinant $\mathrm{Ca}_{\mathrm{V}} 1.2$ and $\mathrm{Ca}_{\mathrm{V}} 1.2$ natively expressed in rat carotid body glomus cells are inhibited by mircomolar concentrations of spermine (Figs. 5 and 6 ). Furthermore, this inhibition leads to a spermine-dependent dampening of the carotid body's response to hypoxia (Figs. 3 and 7). This reduction in the response to hypoxia occurs without a spermine-dependent decrease in hypoxic sensitivity per se, rather it is the result of an attenuated maximal $\mathrm{Ca}^{2+}$ influx, via blockade of $\mathrm{L}$-type $\mathrm{Ca}^{2+}$ channels (Fig. 7).

The calcium-sensing receptor ( $\mathrm{CaR}$ ), a $\mathrm{G}$ protein-coupled receptor which is expressed widely in excitable and non-excitable cells (Riccardi et al., 2009), is exclusively expressed in the nerve endings arborising within the carotid body glomeruli (Fig. 2) and which originate from the petrosal ganglion. Since this structure is not present in either of the preparations (whole carotid bodies and isolated glomus cells), it is not surprising that neither the mRNA encoding the CaR (Fig. 1) nor any functional consequences, by monitoring catecholamine secretion (Fig. 4) and $\left[\mathrm{Ca}^{2+}\right]_{i}$ (Fig. 5), of its expression could be detected. This rules out the possibility that spermine might have been regulating the activity of the carotid body via activation of CaR on glomus cells. Furthermore, the idea that spermine exerts its effects on glomus cells and the whole carotid body via regulation of the L-type $\mathrm{Ca}^{2+}$ current is reinforced by the data in Fig. 6 which show that R-568 does not block $\mathrm{Ca}_{\mathrm{V}} 1.2$.

There are several physiological considerations that arise from our present findings. Spermine is stored at millimolar concentrations in neuronal synaptic vesicles (Masuko et al., 2003) and is co-secreted with neurotransmitters (Fage et al., 1992). Moreover, astrocytes have also been shown to contain high concentrations of polyamines and have been suggested as a major source of extracellular spermine in the brain (Laube and Veh, 1997). Although no data are currently available in the carotid body, it seems reasonable to assume that type 1 cells may well co-secrete spermine with neurotransmitters during stimulation. Such a notion is supported 
A

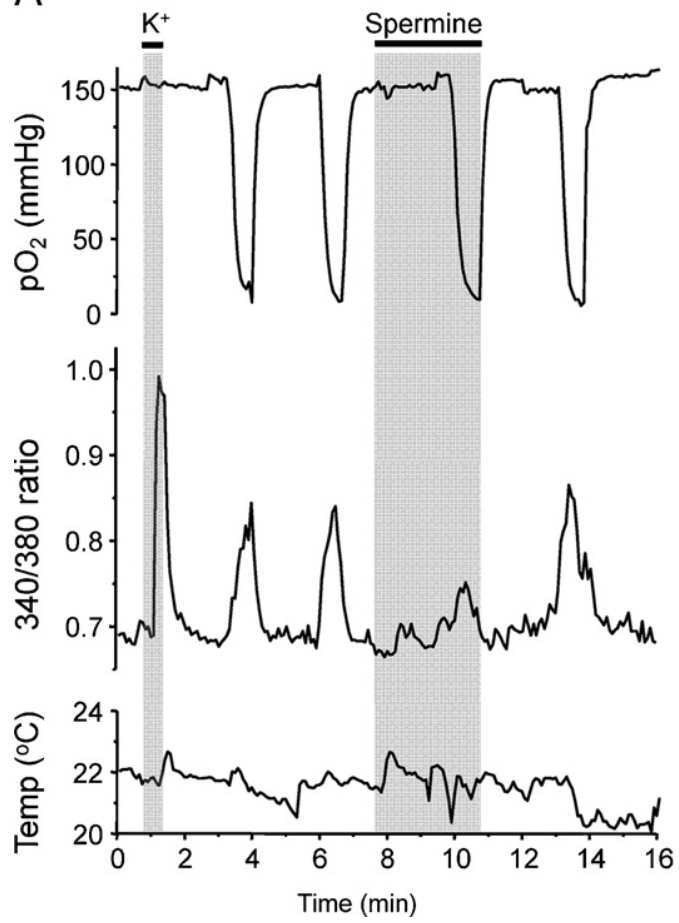

B

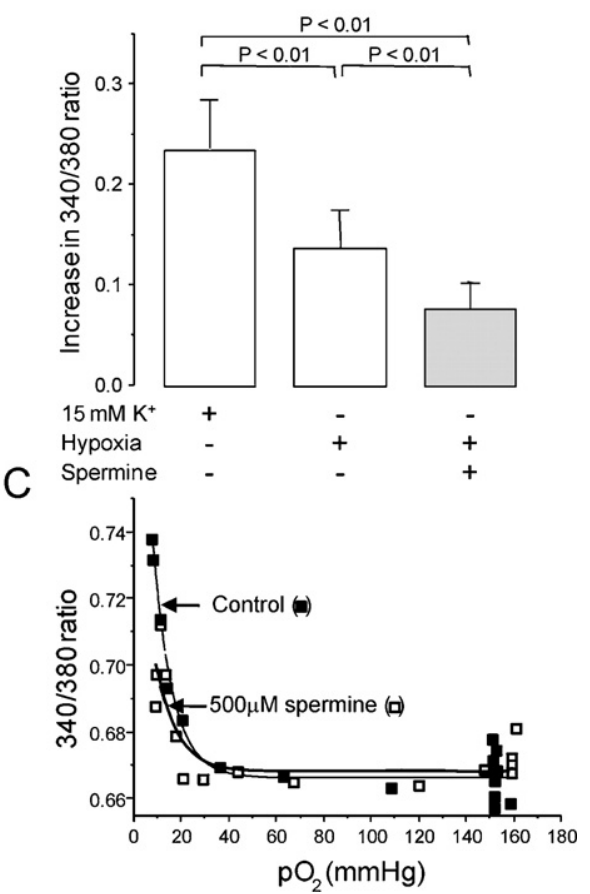

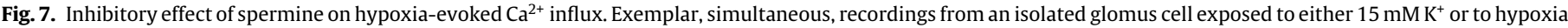

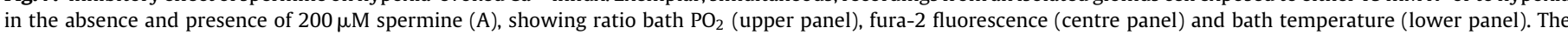

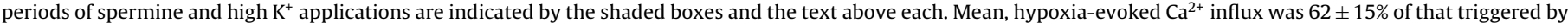

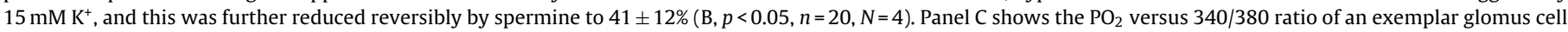

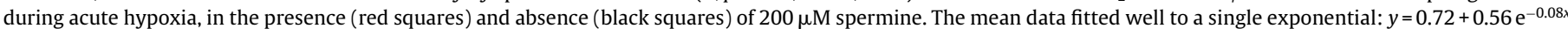

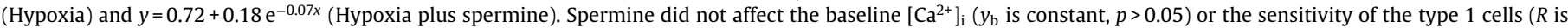

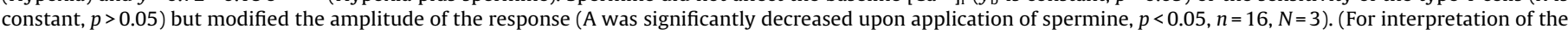
references to color in this figure legend, the reader is referred to the web version of the article.)

by studies in the closely related cell type, PC-12, where there is direct evidence, from capillary electrophoresis with laser-induced fluorescence detection, for co-packaging of catacholamines with polyamines (Du et al., 2004). Therefore, it might be expected that co-secretion of spermine and catacholamines from carotid body might occur as does co-secretion of other transmitters during hypoxia (Gonzalez et al., 1994). Thus, the first potential functional role of spermine would be to reduce the responsiveness of chemoreceptor cells during hypoxic stimulation by limiting the effect of hypoxic depolarization via inhibition of L-type calcium channels. Such an inhibitory mechanism may work in parallel to that proposed for the effect of GABA where, through GABA $A_{B}$ autoreceptors, background potassium currents are re-activated (Fearon et al., 2003). Such auto-feedback mechanisms may act to limit neurotransmitter release by type 1 cells during acute hypoxic challenge. However, since radiolabelled spermine with a specific activity high enough to allow measurement of spermine uptake and release in isolated carotid bodies is now no longer available from any commercial source, this idea cannot be tested directly. Secondly, spermine may also play an important physiological role in adaptation to chronic hypoxia of high altitude and pathologies such chronic obstructive pulmonary disease. Since ornithine decarboxylase is decreased in chronic hypoxia (Ganfornina et al., 2005), it seems reasonable to assume that the attendant reduction is spermine levels may contribute to the structural and functional remodelling of the carotid body during chronic hypoxia, known as acclimatisation, and consisting of an augmentation of the sensitivity and responsiveness of chemoreceptor cells to hypoxia which has been observed in this pathological situation (Bisgard, 2000; Pardal et al., 2007).

\section{Conclusions}

These data show that an endogenously produced polyamine, spermine, exerts a negative influence on carotid body $\mathrm{O}_{2}$ sensing by inhibiting the natively expressed $\mathrm{Ca}^{2+}$ channels. In sum, they suggest that spermine should be considered as a new neuromodulator present in chemoreceptor cells which might contribute to carotid body activity during both acute hypoxic stimulation as well as during chronic hypoxic acclimatisation, acting presynaptically at L-type channels on the chemoreceptor cells themselves.

\section{Acknowledgements}

We thank Amgen, Inc. (grant to DR \& PJK), the Spanish Ministerio de Educacion y Ciencia (grant BFU2007-61848 to CG) and Junta de Castilla y Leon (grant VA104A08 to AR) for funding this work. The authors are grateful to Prof. Chris Peers for his generous gift of the Cav1.2 HEK 293 cells.

\section{References}

Babal, P., Ruchko, M., ult-Ziel, K., Cronenberg, L., Olson, J.W., Gillespie, M.N., 2002. Regulation of ornithine decarboxylase and polyamine import by hypoxia in pulmonary artery endothelial cells. Am. J. Physiol. Lung. Cell. Mol. Physiol. 282, L840-L846.

Belting, M., Mani, K., Jonsson, M., Cheng, F., Sandgren, S., Jonsson, S., Ding, K., Delcros, J.G., Fransson, L.A., 2003. Glypican-1 is a vehicle for polyamine uptake in mammalian cells: a pivital role for nitrosothiol-derived nitric oxide. J. Biol. Chem. 278, 47181-47189.

Bisgard, G.E., 2000. Carotid body mechanisms in acclimatization to hypoxia. Respir. Physiol. 121, 237-246. 
Buckler, K.J., Vaughan-Jones, R.D., 1994. Effects of hypoxia on membrane potential and intracellular calcium in rat neonatal carotid body type I cells. J. Physiol. 476, 423-428.

Caceres, A.I., Gonzalez-Obeso, E., Gonzalez, C., Rocher, A., 2009. RT-PCR and pharmacological analysis of L- and T-type calcium channels in rat carotid body. Adv. Exp. Med. Biol. 648, 105-112.

Casero Jr., R.A., Marton, L.J., 2007. Targeting polyamine metabolism and function in cancer and other hyperproliferative diseases. Nat. Rev. Drug Discov. 6, 373-390.

Cayzac, S., Rocher, A., Obeso, A., Gonzales, C., Kemp, P.J., Riccardi, D., 2009. Effects of the polyamine spermine on arterial chemoreception. Adv. Exp. Med. Biol. 648, 79-104.

Chaisiri, P., Harper, M.E., Griffiths, K., 1979. Plasma spermine concentrations of patients with benign and malignant tumours of the breast or prostate. Clin. Chim. Acta 92, 273-282.

Chattopadhyay, N., Vassilev, P.M., Brown, E.M., 1997. Calcium-sensing receptor: roles in and beyond systemic calcium homeostasis. Biol. Chem. 378, 759-768.

Conde, S.V., Obeso, A., Gonzalez, C., 2007. Low glucose effects on rat carotid body chemoreceptor cells' secretory responses and action potential frequency in the carotid sinus nerve. J. Physiol. 585, 721-730.

Dogan, A., Rao, A.M., Baskaya, M.K., Hatcher, J., Temiz, C., Rao, V.L., Dempsey, R.J., 1999a. Contribution of polyamine oxidase to brain injury after trauma. J. Neurosurg. 90, 1078-1082.

Dogan, A., Rao, A.M., Hatcher, J., Rao, V.L., Baskaya, M.K., Dempsey, R.J., 1999b. Effects of MDL 72527, a specific inhibitor of polyamine oxidase, on brain edema, ischemic injury volume, and tissue polyamine levels in rats after temporary middle cerebral artery occlusion. J. Neurochem. 72, 765-770.

Du, M., Flanigan, V., Ma, Y., 2004. Simultaneous determination of polyamines and catecholamines in PC-12 tumor cell extracts by capillary electrophoresis with laser-induced fluorescence detection. Electrophoresis 25, 1496-1502.

Eterovic, V.A., Torres, E., Ferchmin, P.A., 1997. Spermine does not compete with omega-conotoxin GVIA in the striatum radiatum of the hippocampal slice. Brain Res. 772, 191-202.

Fage, D., Voltz, C., Scatton, B., Carter, C., 1992. Selective release of spermine and spermidine from the rat striatum by $\mathrm{N}$-methyl-D-aspartate receptor activation in vivo. J. Neurochem. 58, 2170-2175.

Fearon, I.M., Palmer, A.C.V., Balmforth, A.J., Ball, S.G., Mikala, G., Schwartz, A., Peers, C., 1997. Hypoxia inhibits the recombinant $\alpha_{1 \mathrm{c}}$ subunit of the human cardiac L-type $\mathrm{Ca}^{2+}$ channel. J. Physiol. 500, 551-556.

Fearon, I.M., Zhang, M., Vollmer, C., Nurse, C.A., 2003. GABA mediates autoreceptor feedback inhibition in the rat carotid body via presynaptic $G_{A B A}$ receptors and TASK-1. J. Physiol. 553, 83-94.

Finney, B.A., del Moral, P.M., Wilkinson, W.J., Cayzac, S., Cole, M., Warburton, D. Kemp, P.J., Riccardi, D., 2008. Regulation of mouse lung development by the extracellular calcium-sensing receptor, CaR. J. Physiol. 586, 6007-6019.

Ganfornina, M.D., Perez-Garcia, M.T., Gutierrez, G., Miguel-Velado, E., Lopez-Lopez, J.R., Marin, A., Sanchez, D., Gonzalez, C., 2005. Comparative gene expression profile of mouse carotid body and adrenal medulla under physiological hypoxia. J. Physiol. 566, 491-503.

Gilad, V.H., Halperin, R., Chen-Levy, Z., Gilad, G.M., 2002. Cyclic changes of plasma spermine concentrations in women. Life Sci. 72, 135-141.

Gomez, M., Hellstrand, P., 1995. Effects of polyamines on voltage-activated calcium channels in guinea-pig intestinal smooth muscle. Pflugers Arch. 430, 501-507.

Gonzalez, C., Almaraz, L., Obeso, A., Rigual, R., 1992. Oxygen and acid chemoreception in the carotid body chemoreceptors. Trends Neurosci. 15, 146-153.

Gonzalez, C., Almaraz, L., Obeso, A., Rigual, R., 1994. Carotid body chemoreceptors: from natural stimuli to sensory discharges. Physiol. Rev. 74, 829-898.

Gonzalez, C., Lopez-Lopez, J.R., Obeso, A., Rocher, A., Garcia-Sancho, J., 1993. Ca ${ }^{2+}$ dynamics in chemoreceptor cells: an overview. Adv. Exp. Med. Biol. 337, 149-156.

Kemp, P.J., Peers, C., 2007. Oxygen sensing by ion channels. Essays Biochem. 43, 77-90.

Kemp, P.J., Peers, C., 2009. Enzyme-linked acute oxygen sensing in airway and arterial chemoreceptors-invited article. Adv. Exp. Med. Biol. 648, 39-48.
Lasater, E.M., Solessio, E., 2002. Regulation of voltage-sensitive $\mathrm{Ca}^{2+}$ channels in bipolar cells by divalent cations and polyamines. Adv. Exp. Med. Biol. 514, 275289.

Laube, G., Veh, R.W., 1997. Astrocytes, not neurons, show most prominent staining for spermidine/spermine-like immunoreactivity in adult rat brain. Glia 19, $171-179$.

Li, J., Doyle, K.M., Tatlisumak, T., 2007. Polyamines in the brain: distribution, biological interactions, and their potential therapeutic role in brain ischaemia. Curr. Med. Chem. 14, 1807-1813.

Longo, L.D., Packianathan, S., McQueary, J.A., Stagg, R.B., Byus, C.V., Cain, C.D., 1993. Acute hypoxia increases ornithine decarboxylase activity and polyamine concentrations in fetal rat brain. Proc. Natl. Acad. Sci. U.S.A. 90, 692-696.

Lopez-Barneo, J., Pardal, R., Ortega-Saenz, P., 2001. Cellular mechanism of oxygen sensing. Annu. Rev. Physiol. 63, 259-287.

Mojet, M.H., Mills, E., Duchen, M.R., 1997. Hypoxia-induced catecholamine secretion in isolated newborn rat adrenal chromaffin cells is mimicked by inhibition of mitochondrial respiration. J Physiol. 504, 175-189.

Masuko, T., Kusama-Eguchi, K., Sakata, K., Kusama, T., Chaki, S., Okuyama, S., Williams, K., Kashiwagi, K., Igarashi, K., 2003. Polyamine transport, accumulation, and release in brain. J. Neurochem. 84, 610-617.

Pardal, R., Ortega-Saenz, P., Duran, R., Lopez-Barneo, J., 2007. Glia-like stem cells sustain physiologic neurogenesis in the adult mammalian carotid body. Cell 131, 364-377.

Persson, L., 2009. Polyamine homoeostasis. Essays Biochem. 46, 11-24.

Quinn, S.J., Ye, C.P., Diaz, R., Kifor, O., Bai, M., Vassilev, P., Brown, E., 1997. The $\mathrm{Ca}^{2+}$-sensing receptor: a target for polyamines. Am. J. Physiol. 273, C1315-C1323.

Riccardi, D., Finney, B.A., Wilkinson, W.J., Kemp, P.J., 2009. Novel regulatory aspects of the extracellular $\mathrm{Ca}^{2+}$-sensing receptor, CaR. Pflugers Arch. 458, 1007-1022.

Rocher, A., Caceres, A.I., Almaraz, L., Gonzalez, C., 2009. EPAC signalling pathways are involved in low $\mathrm{PO}_{2}$ chemoreception in carotid body chemoreceptor cells. J. Physiol. 587, 4015-4027.

Ruat, M., Molliver, M.E., Snowman, A.M., Snyder, S.H., 1995. Calcium sensing receptor: molecular cloning in rat and localization to nerve terminals. Proc. Natl. Acad. Sci. U.S.A. 92, 3161-3165.

Ruchko, M., Gillespie, M.N., Weeks, R.S., Olson, J.W., Babal, P., 2003. Putrescine transport in hypoxic rat main PASMCs is required for p38 MAP kinase activation. Am. J. Physiol. Lung Cell. Mol. Physiol 284, L179-L186.

Scragg, J.L., Dallas, M.L., Wilkinson, J.A., Varadi, G., Peers, C., 2008. Carbon monoxide inhibits L-type $\mathrm{Ca}^{2+}$ channels via redox modulation of key cysteine residues by mitochondrial reactive oxygen species. J. Biol. Chem. 283, 24412-24419.

Silva, M.J., Lewis, D.L., 1995. L- and N-type $\mathrm{Ca}^{2+}$ channels in adult rat carotid body chemoreceptor type I cells. J. Physiol. 489, 689-699.

Sward, K., Nilsson, B.O., Hellstrand, P., 1994. Polyamines increase $\mathrm{Ca}^{2+}$ sensitivity in permeabilized smooth muscle of guinea pig ileum. Am. J. Physiol. 266, C1754-C1763.

Tabor, C.W., Tabor, H., 1984. Polyamines. Annu. Rev. Biochem. 53, 749-790.

Tantini, B., Fiumana, E., Cetrullo, S., Pignatti, C., Bonavita, F., Shantz, L.M., Giordano, E., Muscari, C., Flamigni, F., Guarnieri, C., Stefanelli, C., Caldarera, C.M., 2006. Involvement of polyamines in apoptosis of cardiac myoblasts in a model of simulated ischemia. J. Mol. Cell. Cardiol. 40, 775-782.

Telezhkin, V., Brazier, S.P., Cayzac, S.H., Wilkinson, W.J., Riccardi, D., Kemp, P.J., 2010. Mechanism of inhibition by hydrogen sulfide of native and recombinant BKCa channels. Respir. Physiol. Neurobiol. 172, 169-178.

Vicario, I., Obeso, A., Rocher, A., Lopez-Lopez, J.R., Gonzalez, C., 2000. Intracellular $\mathrm{Ca}^{2+}$ stores in chemoreceptor cells of the rabbit carotid body: significance for chemoreception. Am. J. Physiol. Cell. Physiol. 279, C51-C61.

Vizard, T.N., O'Keeffe, G.W., Gutierrez, H., Kos, C.H., Riccardi, D., Davies, A.M., 2008. Regulation of axonal and dendritic growth by the extracellular calcium-sensing receptor. Nat. Neurosci. 11, 285-291.

Wang, R., Xu, C., Zhao, W., Zhang, J., Cao, K., Yang, B., Wu, L., 2003. Calcium and polyamine regulated calcium-sensing receptors in cardiac tissues. Eur. J. Biochem. 270, 2680-2688. 